\title{
Grimalkin and other Shakespearean Celts
}

\author{
Andrew Hadfield \\ University of Sussex, UK
}

\begin{abstract}
This essay examines the representation of Ireland and Celtic culture within the British Isles in Shakespeare's works. It argues that Shakespeare was interested in ideas of colonisation and savagery and based his perceptions on contemporary events, the history of the British Isles and important literary works such as William Baldwin's prose fiction, Beware the Cat. His plays, notably The Comedy of Errors and Macbeth, represent Protestant England as an isolated culture surrounded by hostile Celtic forces which form a threatening shadowy state. The second part of the essay explores Shakespeare's influence on Irish culture after his death, arguing that he was absorbed into Anglo-Irish culture and played a major role in establishing Ireland's Anglophone literary identity. Shakespeare imported the culture of the British Isles into his works - and then, as his fame spread, his plays exported what he had understood back again, an important feature of AngloIrish literary identity, as many subsequent writers have understood.
\end{abstract}

KEYWORDS: Colonisation; drama; English Renaissance Literature; Ireland; savagery; Shakespeare; James Shirley.

This essay was first given as the Shakespeare birthday lecture at the Folger Shakespeare Library, Washington DC in 2013. I am extremely grateful for the invitation and for the feedback I received on that occasion.

$$
\text { (E) ederi 25 (2015: 55-76) }
$$


Who was Grimalkin? The OED cites the opening of Macbeth as the origin of the name of this supernatural creature:

FIRST WITCH When shall we three meet again?

In thunder, lightning, or in rain?

SECOND WITCH When the hurly-burly's done,

When the battle's lost, and won.

THIRD WITCH That will be ere the set of sun.

FIRST WITCH Where the place?

SECOND WITCH Upon the heath.

THIRD WITCH There to meet with Macbeth.

FIRST WITCH I come, Graymalkin!

SECOND WITCH Paddock calls.

THIRD WITCH Anon.

ALL Fair is foul, and foul is fair,

Hover through the fog and filthy air. (Shakespeare 1990:1.i.112).

Notes on the play will tell you that Grimalkin was a cat, a witch's familiar, the name Malkin being a diminutive of Mary so that the witches appeal to their familiars, a cat and a toad (Paddock). Paddock is a common English term for a toad or a frog, dating far back into Middle English and even appearing in the Wycliff Bible, as the OED again informs us. But the OED is wrong about Grimalkin in ways that are all too recognisable. Shakespeare - or Middleton who may have written these witch scenes, drafted in by the Kings' Men as the most prestigious writer of witch scenes (Middleton 2007:1165-69) - took the name from one of the most important and underrated works of sixteenth-century English literature, William Baldwin's Beware the Cat, a work which has a strong claim to be the first novel in English (Ringler 1978-1979; Herron 2013:77 n.55). Baldwin's prose fiction, which had a profound influence on the course of English literature, was written in the 1550 s but not published until 1570 .

Shakespeare was likely to have known the work. Baldwin was the literary superstar of the mid-Tudor period and was also responsible for $A$ Mirror for Magistrates, a major literary text that 
played a key role in making Shakespeare into Shakespeare (Bullough 1962:III, 229-33, passim; Tillyard 1969:77-96). Beware the Cat is a work of profound paranoia, written at the height of religious change and confusion in the aftermath of the Reformation. Baldwin had become a major literary force at the court of Edward VI, a fiercely Protestant monarch, but after his death aged 16 in 1553, his committed Catholic sister, Mary, became queen, changed things around, and Baldwin's star seems to have faded dramatically (Gresham 1981). Baldwin's prose fiction represents a shadow state whereby the human world is parodied, fed upon, imitated and closely watched by the cats who are like us but not quite, just as they are Catholics and like us but not quite, as many of us are Catholics too (Maslen 1997:75-82). Baldwin describes a religious and political situation in which no one was comfortable and no one knew where to turn. Not only did people not know if their neighbours were Catholics or heretics, or whether Catholics and heretics were actually right really, they did not know if they were actually heretics or even really Catholics.

Baldwin's narrator, Master Streamer, represents the story of the death of Grimalkin, which takes place after a cattle raid, an ancient Irish tradition that fascinated English observers. A kern (an Irish soldier) and his boy stop to eat a stolen sheep, their spoil for the day, along with a cow:

And while this kern was in the church he thought it best to dine, for he had eaten little that day. Wherefore he made his boy go gather sticks, and strake fire with his feres, and made a fire in the church, and killed the sheep and after the Irish fashion laid it thereupon and roasted it. But when it was ready, and that he thought to eat it, there came in a cat and set her by him, and said in Irish, "Shane foel," which is, "give me some meat." He, amazed at this, gave her the quarter that was in his hand, which immediately she did eat up, and asked more till she had consumed all the sheep; and, like a cormorant not satisfied therewith, asked still for more. Wherefore they supposed it was the Devil, and therefore thinking it wisdom to please him, killed the cow which they had stolen, and when they had flayed it gave the cat a quarter, which she immediately devoured. Then they gave her two other quarters. (Baldwin 1988:13).

The story is unsettling. Is Baldwin laughing at the superstitious Irish, or are they uncomfortably close to home? What would others have done when confronted by such an insanely greedy talking cat? 
(Animals talking in literature are often very dubious, like the talking black dog, a manifestation of the devil, in The Witch of Edmonton; Rowley, Dekker and Ford 1997). And, is this description an acknowledgement that the Irish, even if they did treat a sacred place like a kitchen, faced similar problems to their confused English counterparts and were not radically different people?

Eventually the cat eats the whole cow and the men flee fearing that they are next on the menu, which turns out to be true. The cat chases the kern but he kills her with his dart. However, "immediately afterwards there came to her [i.e., the dead Grimalkin] such a sight of cats that, after long fight with them, his boy was killed and eaten up" (Baldwin 1988:14). The kern escapes and tells his wife what has happened, at which point his wife's cat, silent until now, exclaims "Hast thou killed Grimalkin," and "therewith she plunged in his face, and with her teeth took him by the throat, and ere that she could be plucked away, she had strangled him" (Baldwin 1988:14). Most significantly, perhaps, the news subsequently reaches England and a Staffordshire native, riding through Kankwood, has his own experience of the effective news network operated by the cats:

a cat, as he thought, leaped out of a bush before him and called him twice or thrice by his name. But because he made none answer nor spake (for he was so afraid that he could not), she spake to him plainly twice or thrice these words following: "Commend me unto Titton Tatton and to Puss thy Catton, and tell her that Grimalkin is dead." This done she went her way, and the man went forward about his business. And after that he was returned home, in an evening sitting by the fire with his wife and his household, he told of his adventure in the wood. And when he had told them all the cat's message, his cat, which had harkened unto the tale, looked upon him sadly, and at the last said, "And is Grimalkin dead? Then farewell dame," and therewith went her way and was never seen after. (Baldwin 1988:11)

The spread of news was a new, exciting and anxiety-inducing phenomenon in this period. News could be circulated in broadsheet form but it was invariably a slow process in this early period of the printing press and the start of unified transport systems, which were still fairly primitive in this period and the awful state of roads made it easier to travel by water (Pettegree 2014: chs. 1-3). Nevertheless, the cats still manage to get their message spread around by different 
means and make use of human intermediaries to do this so that news of Grimalkin's death gets from south-west Ireland to central England (Cannock Wood). Baldwin shows the shadow state working with great success. What this alternative kingdom of the cats actually is - sometimes it looks like the human world, at others has quite a different character - is another matter.

\section{II}

I think that it is likely that the link made between Ireland and England in Beware the Cat had a significant impact on Macbeth. The names of the witches' familiars "paddock" and "Grimalkin" were probably not chosen at random. "Paddock" is an old English word; "Grimalkin" one explicitly associated with Ireland, and the witches are uttering their chants in Scotland. What an audience would hearassuming that they associated Grimalkin with Ireland - is that a shadow state of witches surrounds, encircles and undermines the actions of the human world, a message entirely in keeping with the ancient supernatural and morally disturbing elements in the play. Macbeth represents the early medieval British Isles under the sway of spirits like Grimalkin, long before his/her death. Witches are associated here with a Celtic twilight world that is unseen until one strays into it, as the Macbeths unfortunately do. What we witness in Scotland is part of a rarely seen spirit world that threatens to engulf the visible and familiar nature of everyday life.

And, indeed, in this period there was a topical point to be made. Macbeth is a British play, along with King Lear and Cymbeline, works that represented the ancient past but which were informed in complex ways by the prospect of a union of the British Isles under a Scottish king (Mottram 2013; Power 2013). Shakespeare did not write such plays in the 1590 in the first half of his career under Elizabeth: he wrote English history plays looking back to the Wars of the Roses and the impact of the deposition of a king, Richard II, works that clearly spoke to the anxiety surrounding the succession crisis (Hadfield 2004). We have no reason to think that Shakespeare ever went to Ireland - although attempts have been made to make this case (Plunket Barton 1919). What his drama reveals, however, is that writers who had no obvious connection with Ireland or Scotland had to think about the relationship between those nations and England 
before and after the partial union of 1603 (Levack 1987). In the 1590s the fear in England was that a Catholic pincer movement might link resistance to English rule in Ireland - the rebellion of Hugh O'Neill which developed into the Nine Years War - with the Scottish Stuart claim to the English throne, the legacy of Mary Queen of Scots through her son, James VI (Connolly 2007: ch. 6). After James had become king of the three kingdoms - Wales had been forcibly united with England between 1535 and 1543 - rather different questions surfaced (Ivic 2013). It is at least arguable that The Tempest, which makes no reference to Ireland, actually has recent events in Ireland in mind at key moments, as the following exchange would indicate (Hamilton 1990; Baker 1997):

GONZALO Had I plantation of this isle, my lord,-

ANTONIO He'd sow't with nettle-seed.

SEBASTIAN Or docks, or mallows.

GONZALO And were the king on't, what would I do?

SEBASTIAN 'Scape being drunk for want of wine.

GONZALO I' the commonwealth I would by contraries

Execute all things; for no kind of traffic

Would I admit; no name of magistrate;

Letters should not be known; riches, poverty,

And use of service, none; contract, succession,

Bourn, bound of land, tilth, vineyard, none;

No use of metal, corn, or wine, or oil;

No occupation; all men idle, all;

And women too, but innocent and pure;

No sovereignty;-

SEBASTIAN Yet he would be king on't.

ANTONIO The latter end of his commonwealth forgets the beginning.

GONZALO All things in common Nature should produce

Without sweat or endeavour: treason, felony,

Sword, pike, knife, gun, or need of any engine,

Would I not have; but nature should bring forth,

Of its own kind, all foison, all abundance,

To feed my innocent people.

SEBASTIAN No marrying 'mong his subjects?

ANTONIO None, man; all idle: whores and knaves. 
GONZALO I would with such perfection govern, sir,

T'excel the Golden Age. (Shakespeare 1980:II.i. 138-53)

As is well-known, the words of Gonzalo draw on Montaigne's essay "Of the cannibals," John Florio's translation of Montaigne's Essays being one of the books that Shakespeare surely owned and used extensively (Bate 2008:109-10; Greenblatt and Platt, eds. 2014:xxviixxviii). But the use of the word "plantation" undoubtedly refers us to the recent establishment of a plantation in the British Isles, the Ulster Plantation, formally begun in 1611, but started earlier using funding from the Livery Companies in London to establish the Londonderry Plantation (Ó Ciardha and Ó Siochrú, eds. 2012). The plantation was designed to unite Scots, Irish and English with the same ideal, i.e., to civilize Ireland and to make Ulster profitable, a project that bears a striking resemblance to that of the witches' shadow state in Macbeth, the one seeking to combat what it imagined was the frightening reality of the other. Ulster had been the site of most sustained resistance to English rule after the crushing of the House of Desmond in south-west Ireland in the early 1580s, a large forested area that was ideal territory for the guerilla tactics of O'Neill's forces. Two of O'Neill's most significant victories - and most embarrassing English defeats - had taken place in Ulster, the Battles of the Ford of the Biscuits (1594) and the Yellow Ford (1598) (Connolly 2007:232, 242). Deforesting and flattening the province and establishing a series of farmers loyal to the crown seemed like good sense and good business to many. When The Tempest was written and produced, 1610-1611, plantation was very much on peoples' minds, in part, of course, because of the recent establishment of the Virginia colony (1607) (Sonner 2013). Gonzalo wants to start from scratch and establish the Golden Age, a project that can be related to the desire to plant colonies in the New World, something that plays such as the cynical London city comedy, Eastward Ho!, printed in 1605 , had already satirized as a plan for greedy citizens to extort more wealth from unfortunate victims (Knowles, ed. 2001). However, the word "plantation" was much more specifically associated with The Ulster Plantation, an enterprise that was also much closer to home than the New World colonies and so more obviously in people's minds: no one really thought that a new Golden Age would dawn in the north of Ireland. The hope was, nevertheless similar. Its architects wanted to start a new, more unified society, something heavily promoted by the king, who was 
very keen on the idea of Plantation, and articulated by Sir Francis Bacon in his essay, "Of plantations," which argued that if settlers treated natives well they would soon realize that all shared a common goal (Bacon 1972:104-106). Is Shakespeare supporting efforts to plant civility in Ireland? Or satirizing them? It is hard to tell without exploring his representations of Ireland throughout his work.

\section{III}

Ireland features regularly in Shakespeare's works, almost always as an incomprehensible land that threatens civilized stability. This is the case even in what might seem to be the lightest of comedies. In The Comedy of Errors we have a description of Nell, Adriana's kitchen maid, provided by Dromio of Syracuse, who is eager to resist her advances. As T. W. Baldwin pointed out in his substantial analysis of the play, Dromio's description of Nell works well as "a disquisition on politics" dealing with events around the year 1590, something that would have been of great interest to the audience at Gray's Inn where the play was first performed on 28 December 1594 (Baldwin 1965:2).

Dromio provides a rather unflattering description of Nell's body in the form of a blazon, a familiar poetic motif that surveyed a woman's body from her head down to her feet. Dromio suggests that Nell's forehead is her France; England, her chin; Spain, her hot breath; America, her nose; and the Netherlands, her nether parts. Antipholus asks "In what part of her body stands Ireland?," the answer being "Marry, sir, in her buttocks, I found it out by the bogs" (Shakespeare 2004:3.2. 105-106). The sense is clear enough: Baldwin rather coyly notes that this is a "traditional gibe" and the play's editor. T. S. Dorsch, suggests that it is "Probably a quibble, with connotations of 'privy'" (Baldwin 1965:1; Shakespeare 2004:91).

I think the joke has a very specific resonance - exactly like the Grimalkin reference - which indicates that Shakespeare was interested in popular lore about Ireland - as were so many of his contemporaries (Shakespeare's reference to Irish wolves howling at the moon in As You Like It is another example of a short-hand reference to the wildness and savagery of Ireland for an English audience; 1975:V.ii.110-111). The use of the word "bogs" very likely 
recalls a description contained in John Derricke's The Image of Irelande (1581). Derricke's long poem, which depicts the savage nature of the Irish "kern" [soldiers] and represents the Irish as unnatural and ungrateful subjects of the crown always eager to rebel was one of the key works on Ireland published in Elizabethan times and probably second only to Holinshed's Chronicles - that favourite source of Shakespeare's plays - for providing information for English readers eager to learn about Ireland and the Irish. Derricke's text was lavishly illustrated with twelve woodcuts, among the best reproduced in any English book in the sixteenth century, many of which have become quite justly famous. The pictures show an Irish feast complete with bards; English troops marching through the Irish countryside; the surrender of an Irish chieftain to the Lord Deputy, Sir Henry Sidney; and the dramatic repentance of the outlaw rebel, Rory Oge O'More. Derricke's text was probably the main source of information on Irish life apart from verbal reports, personal experience, or official propaganda, for the vast majority of Londoners in Elizabethan England.

Part One of The Image of Irelande contains a description of Irish eagles which prefer to nest not "in the bounds of Englishe pale, | which is a ciuill place:|But in the Deuills Arse, a Peake, | where rebels moste imbrace" (Derricke 1883:41). Derricke makes an explicit connection between savagery and on obsession with the anus, a common enough link in contemporary travel writing (Sheehan 1980:49-51). A few lines later he describes "the boggs" as the natural habitat of the Irish kern:

Yea though thei were in Courte trained up,

And yeres there lived tenne:

Yet doe thei loke to shaking boggs,

Scarce provying honest menne.

And when as they have wonne the Boggs,

Suche virtue hath that grounde. (Derricke 1883:42)

Ireland was full of bogs, and anyone passing through the Irish midlands had to navigate the Bog of Allan, of which Spenser complained so bitterly because of the ferocious Irish gnats. Bogs also brought the dangers of disease because of their damp climate, especially dangerous for English soldiers and settlers unfamiliar with their effects (Irish sickness killed more English soldiers than Irish kern) (Herron 2006:94; Lennon 1995:8-9). Derricke shows the Irish preferring life in the hostile regions of their country, the peaks 
and the bogs, both places which are contrasted to the civilized life of the English Pale around Dublin. Gravitation to such areas was in itself an indication of a savage nature resistant to civilization. It would seem highly unlikely that there is not some connection between Derricke's poem and Shakespeare's play, whether the influence of the former on the latter was direct or indirect. It may well be that Dromio is making a new pun by exploiting the geographical proximity between the "Arse" and the "bogs" in Image of Irelande, repeating Derricke's joke, or that both are employing a general joke that has become obscure for us. Further evidence is provided in the image of the open air Irish feast in the Image of Irelande, the most frequently reproduced image of Tudor Ireland. This shows a number of details which represent Irish behavior as uncivilized: the insanitary and unhygienic cooking and eating arrangements; the mangy dog chewing a bone in the front centre; as well as the Irish love of entertainment at such events, the bard reciting a poem, and the harper accompanying him. Two figures on the extreme right of the picture are shown bearing their backsides. This makes an explicit link between the consumption of food and its expulsion from the body, again showing how the English represented the Irish as extremely anal in character, having disorderly and uncontrollable bodies, a real sign of a lack of rational purpose so carefully represented in this period. Shakespeare's representation of Nell is clearly in this tradition of English perceptions of the Irish, both Derricke and Shakespeare linking the Irish to the anus.

\section{IV}

Ireland posed a direct threat to England in the 1590s, as it had done in earlier periods. As the Tudors were acutely aware, both Lambert Simnel and Perkin Warbeck, pretenders who both falsely claimed to be Richard, Duke of York, one of Edward IV's sons murdered in the Tower built up their forces in south-west Ireland ready to launch invasion forces to England (Ellis 1985:70-86). In Shakespeare's English history plays Ireland is where opposition to the English crown develops and grows. Richard Duke of York establishes his military challenge to the ineffective rule of Henry VI in Ireland in Henry VI, Part 2. Richard is sent across St. George's Channel by Cardinal Beaufort, the Protector, to stem the rebellion of "Th'uncivill 
kerns of Ireland" who "are in arms | And temper clay with blood of Englishmen" (yet another reference that establishes the savage and bloody nature of everyday life in Ireland) (Shakespeare 1999:3.1.30910). Sending York to Ireland is a disastrous manoeuvre, as York's soliloquy immediately afterwards demonstrates. York is quite explicit that he has enlisted Jack Cade to stir up trouble in England to support his own assault upon the throne. When we witness Cade's rebellion in full swing, the pissing conduits about to run with wine and the lettered all facing execution out of class spite, we know that it has an aristocratic origin and is part of a larger plot to seize the crown. Ireland is used by English rebels as a means of importing two inter-related rebellions to England, those of York and Cade, which shall create widespread civil war as England implodes into furious conflict and slaughter: or, as York puts it, he will stir up "in England some black storm |Shall blow ten thousand souls to heaven or hell" (Shakespeare 1999:3.1.349-50). Cade is described as bestial, "like a sharp-quilled porpentine" who can "caper upright like a wild Morisco, |Shaking the bloody darts as he his bells" (Shakespeare 1999:3.1.362, 364-65). He has actually become "like a shag-haired crafty kern" (Shakespeare 1999:3. 1. line 366), suggesting that his experience in Ireland has made him Irish, or, perhaps, Hiberniores Hibernis ipsis, more Irish than the Irish themselves, as critics of English settlers in Ireland often complained, noting that English people in Ireland "degenerated" (Maley 1997a: ch. 3). York's plan is made clear in his conclusion: "from Ireland come I with my strength |And reap the harvest which that rascal [i.e., Cade] sowed" (Shakespeare 1999:3.1.379-80). York will return to England as the iconic figure, the sower of death: what he does not realise is that one of the deaths will be his own, brutally taunted by Queen Margaret with a paper crown and anointed with the blood of his dead son. The play is remarkably prescient of the fate of the earl of Essex represented in Henry $V$. Essex was supposed to bring rebellion back "broached on his sword," as the chorus to Act V put it. Instead he built up his army of soldiers and brought back rebellion in a different way, which led to his execution (Patterson 1989: ch. 4).

York refers to Cade as a Morisco, suggesting that his experience in Ireland transforms him into an exotic creature like someone from North Africa. York's words further indicate that he regards the Irish as an alien people, useful when they serve his purposes but inherently different and, ultimately, disposable. Cade might as well 
be a battle-hardened Morisco as an Irish kern as far as York is concerned: either one will serve his purposes. But it is not clear that Shakespeare sees matters quite this way: after all, York pays dearly for his assumptions and his hazy racism may be a central cause of his downfall, suggesting that he can only see creatures who will aid his rise to power, not people.

Richard II is another king who pays for his failure to understand Ireland and his ill-conceived and ill-fated Irish campaign enables Bolingbroke to establish the army that will make him Henry IV. On his return to his kingdom where he will lose his crown and his life Richard speaks in defiance of the growing power of Bolingbroke in words that are eloquent, as Richard invariably is, but which contain a bitter series of ironies:

So, when this thief, this traitor, Bolingbroke, Who all this while hath revelled in the night Whilst we were wand'ring with the Antipodes, Shall see us rising in our throne, the east, His treasons will sit blushing in his face,

Not able to endure the sight of day,

But self-affrighted, tremble at his sin.

Not all the water in the rough rude sea

Can wash the balm off from an anointed king;

The breath of worldly men cannot depose

The deputy elected by the Lord. (Shakespeare 2002:3.2. 47-57)

Does Richard really think he has been wandering in the Antipodes? Surely not, but the metaphor exposes him as the description of Cade as a Morisco exposed Richard Duke of York. King Richard clearly has a careless regard for a land he ostensibly governs, as English kings were lords of Ireland after the Norman conquest of Ireland justified by Pope Adrian II's Laudabiliter of 1155, which granted Ireland to the English crown and church (Ellis 1985:191). He has an insouciant disregard for the realities of people he rules, always a dangerous tendency for a king, especially a Shakespearean king. Just as he does not really care -or know- who his Irish subjects are neither does he care who his English subjects are or what they want. Hence the rolling power of the last four lines quoted here which represent the monarch in splendid isolation from the people. Richard sees this as a strength which makes him untouchable but such theories of kingship made the power of monarchs brittle and their rule vulnerable (Hadfield 2004:ch. 1). Richard's lines sound 
impressive but he is about to be deposed because it takes even less than the breath of men and rough seas to separate a king from his crown, as the play shows us. Richard, as if we didn't know already, has lost sight of reality, his royal visit to Ireland only serving to undermine him, in large part because he simply does not know or understand what or why he governs.

Perhaps we should not be too hard on him. As these two plays show, kings were damned if they went to Ireland and damned if they sent someone else. A number of Lord Deputies got into trouble for their activities, notably usurping royal prerogative, Leonard Grey being executed in 1541; Sir John Perrot would probably have been executed in 1592, but died before his trial; Arthur Lord Grey de Wilton appears to have been recalled not because of his notorious actions at the Fort D'Oro in Smerwick Harbour in 1580, when 600 unarmed papal troops were put to death after they had surrendered, but because he was felt to have exceeded his brief in deciding who should live and who should die while he put down rebellion in Munster, and for doling out titles and favours to his followers (Ellis 1985:136, 281-84; Morgan 1995). Any governor in Ireland was in an uneasy position: a vice-regent standing for the monarch always ran the risk of usurping their power. Shakespeare's history plays acknowledge the anxieties that this ambiguous position generated and undoubtedly reflect back some of the nervousness experienced in the 1590 as the Nine Years War developed to threaten English rule in Ireland, as the figures of Richard, Duke of York and Richard II demonstrate. Crossing the Irish Sea might well wash the anointed balm from a king; but letting someone else cross the sea on your behalf and in your name could have the same effect.

The problem is represented in its most acute form in Henry $V$. As Jim Shapiro has pointed out Henry $V$ is an "at war" play, produced while the largest army ever to leave England's shores gathered in London ready to go over and crush Irish resistance (Shapiro 2005: ch. 5). The play is replete with the fear of imminent conflict because the enemy in that play is not really France, but Ireland. After the French defeat Queen Isabel celebrates the forthcoming marriage of her daughter by accidently referring to her future son-in-law as Irish: "So happy be the issue, brother Ireland, |Of this good day and of this gracious meeting" (Shakespeare 1982:V.ii.12-13). The reason for this slip is probably not scribal or textual but "an indication of [a] 
preoccupation with Irish affairs," according to the play's editor Gary Taylor (Shakespeare 1982:266). It is little wonder that the play is so concerned with questions of identity and that Captain MacMorris, the Anglo-Irish soldier in the four nations army that Henry leads can ask, "What ish my nation?" (Shakespeare 1982:III.iii. line 63), a much commented upon verbal crux that suggests that identities were not stable at this point (Neill 1994). However we read MacMorris's question, whether he is challenging the notion that Scots, Irish, Welsh and English have any real distinct identity in Henry's British army, as Philip Edwards argued, or whether he is taking umbrage at an assumption that he is Irish rather than Anglo-Irish, as other commentators have suggested, the point is that the play defines an unstable moment when people were unsure who they were or who they were going to be in the years to come, whether events in Ireland were going to change the nature of the archipelagic cluster of the British Isles (Edwards 1979:74-86; Maley 1997b).

\section{V}

However, things looked very different only a few years later, and it is often hard for us to appreciate and understand the extent and nature of this transformation. In part it is because we are continually confronted with images of Elizabeth as a great queen and have little real understanding of James as a king. Shakespeare is habitually represented as an Elizabethan playwright, even though his career was only half over by the time the old queen died. English perceptions of the world changed dramatically in 1603-1604 as James made peace with Spain and the war in Ireland ended dramatically and suddenly on Christmas Eve 1601 when Lord Mountjoy's forces comprehensively defeated the Spanish and Irish army at the Battle of Kinsale to end the Nine Years War (Silke 1970).

James had a great interest in uniting the kingdoms he now ruled, which meant assimilating and civilising Ireland. Soon after his accession to the English throne James recognised just how significant Ireland had been when he looked through the collection of state documents and exclaimed, "We had more ado with Ireland than all the world besides" (Bradshaw, Hadfield and Maley, eds., 1993:6). James's most significant act was to establish the Ulster Plantation, but the transformation of the relationship between England, Ireland 
and Scotland during James's reign led to other interesting cultural exchanges. Renaissance drama hardly attracted the same reverence in the early seventeenth century that it was to achieve after the Restoration. However, with the publication of Ben Jonson's folio in 1616 drama became a significant element of English cultural identity, plays now considered alongside poetry as serious literature (McMillin 1999). It probably helped that in the same year a folio of James's works first appeared, as unique an event in the history of monarchy as Jonson's was for a playwright, the two substantial volumes transforming the history of English publishing.

Shakespeare imported a number of Irish themes into his work to show how fragile and threatened English civilisation was; now his work was exported back to Ireland as part of a civilising mission. It should not surprise us that the first recorded attempt to perform a Shakespeare play in Ireland was on the Ulster Plantation, in Coleraine, a sign that the civilising mission was directly associated with the dissemination of literary culture. This was an "attempt" because the performance did not actually take place. The planters planned to stage a play as an entertainment for the visiting Plantation commissioners when they visited the town in May 1628, selecting Much Ado About Nothing as an appropriately entertaining work. Unfortunately, as Alan Fletcher points out, the performance was called off because of a song that offended the visiting commissioners, probably a satirical jibe aimed at the London agents who oversaw the colony's finances and who were attempting to remove Sir Thomas Phillips the head of the colony. Phillips letter notes that the "Commissioners [...] Tooke a Song that was sung [...] soe much to hart [...] that they durst not play the play for feare of offending the Commissioners" (Fletcher 2000:239). It seems to be a mystery that we will never really solve, but, as Fletcher points out, the aborted event indicates that by the late 1620 settlers in Ulster "were not so entirely preoccupied with their planting as to lose all sense of the value of drama and the performing arts" (Fletcher 2000:240). More specifically one might conclude that drama was seen to be an important element of the colonised nation's cultural life, as well as noting the dramatic change in the manner of everyday life in Ireland from the 1590 s to the 1620s. The selection of Shakespeare suggests that his reputation as the pre-eminent English dramatist was already underway and points forward to the significant role his 
works were to play in defining the nature of the Irish stage up to the twentieth century.

There were undoubtedly other performances of Shakespeare plays in great households that have remained unrecorded. If an acting company could be raised to stage plays in Coleraine, surely plays could have been staged in Dublin and the Pale in the same period. The first professional theatre was established in Ireland in 1636, near Werburgh Street, Dublin. Werburgh (or Warber) Street, was right in the centre of the early modern city, perhaps indicating the significance of the establishment of a professional theatre for the Anglo-Irish government in Dublin, and a pointed contrast to the theatre, bear-baiting and pleasure pursuit area which dominated the south bank of the Thames in Elizabethan and Jacobean London. The first Master of the Revels in Ireland, John Ogilby, took on the role, as Chris Morash has pointed out in his history of Irish theatre, at a "propitious" time (Morash 2002:4). The London theatres were closed because of the plague and the new Dublin theatre was able to secure the services of a major playwright, James Shirley. Shirley, who did not always seem to enjoy his new post, produced a number of important works for the theatre in his brief tenure as resident playwright. His weird and wonderful fantasy about the establishment of Christianity in Ireland, St. Patrick for Ireland was staged in 1639, with its tactless prologue wishing that there were at least a few in the audience who "Knew but the art and labour of a Play" and could "value the Muses plaine, | The throwes and travel of a teeming braine" (Shirley 1640:A2r). Obviously the civilizing mission of the theatre was not going quite to plan and St. Patrick for Ireland certainly pays the audience back in representing St. Patrick as "no controversial Catholic icon but the thoroughly English saint, bringer of civilisation to Irish shores, documented by James Ussher" (Rankin 2005:102). Perhaps Shirley's play before St. Patrick had not gone down well with a Dublin audience not receptive to his work or as eager to be challenged as the dramatist had expected.

What is noticeable about Shirley's Irish plays is that they are, in the main, distinctly Shakespearean in style and substance. The Politician, also staged in 1639, is a play closely related to Hamlet. The play's action takes place in Norway, an unusual setting for Shirley. The plot revolves around an unscrupulous politician, Gotharus, eager to control the throne through his actions behind the scenes. He 
persuades his mistress, Marpisa, to marry the king hoping to place Haraldus, her weak, illegitimate son by a former affair, on the throne. Needless to say the plot goes hopelessly wrong and all the villains die, taking a few victims with them, such as poor, silly Haraldus, who, unable to cope with liquor, dies of a fever after Gotharus gets him drunk. Although the King, realising how wrong he has been about virtually everything, offers to abdicate, his son, Turgesius, strongly supports his continuation as monarch, and he remains in power. Turgesius sensibly prepares for the future by marrying Gotharus's virtuous widow, Albina, and so restoring some sense of order and proper succession.

The play opens, like Hamlet, with reports of a dubious and illconsidered marriage:

CORTES It was a strange and suddaine marriage.

HORMENUS Could he not love her for the game, and so forth,

But he must thus exalt her? no lesse title

Then Queen, to satisfie her ambition? (Shirley 1655:1)

Gotharus then enters, muttering to himself, and in the process he reveals to the audience that he has had Turgesius sent away to fight a war in the hope that he will not return, but his plans have been thwarted by an unexpected victory:

GOTHARUS Curse upon his victory!

I meant him not this safety, when I wrought

The King to send him forth to warre, but hop'd

His active spirit would have met some engine

To have translated him to another world;

He's now upon return. (Shirley 1655:2)

The first exchange would clearly have reminded readers of the untimely union between Claudius and Gertrude; the second of Claudius's plot to dispatch Hamlet in England at the hands of Rosencrantz and Guildenstern in Act 4. As the play progresses far more links to Hamlet become clear, notably that Marpisa appears as an exaggerated version of who Hamlet thinks his mother is when he confronts her in her closet and the discussion of kingship revisits the issues surrounding elective kingship in Shakespeare's play. Was this just Shirley's mode of writing and homage to the master? Or was Shirley consciously reproducing these elements as particularly appropriate for the Irish stage? Either way, Shirley's plays demonstrates how Shakespeare's work was exported to Ireland in 
the early years of its first theatre, a process that became even more apparent with the establishment of the second theatre in Ireland, Smock Alley in 1662, again overseen by John Ogilvy. Situated at Wood Quay, like many Restoration Theatres its productions were dominated by Shakespeare plays: "Hamlet, Julius Caesar, King Lear, Macbeth, Othello, Troilus and Cressida, Henry VIII, Henry IV: Parts I and 2, The Merry Wives of Windsor, A Midsummer Night's Dream, Twelfth Night, Measure for Measure, The Tempest, and possibly The Comedy of Errors -more or less the staples of the Irish stage for the next century or more" (Morash 2000:18). The Irish stage of the early seventeenth century was conspicuously Shakespearean in character.

\section{VI}

In his play, Mutabilitie, first staged in 1997, Frank McGuinness provided a striking contrast between the rigid, hierarchical views of the Irish bards and the major English poet in Elizabethan Ireland, Edmund Spenser (Grogan 2013:36-43). These old-fashioned cultural figures were contrasted to the open-minded playwright, William, who is eager to learn about Irish culture. Here he is in conversation with Hugh O'Neill, an Irishman who is also open-minded enough to want to learn something about the English who have invaded his country:

WILLIAM: Your master has taught you well.

HugH: He did not teach me. I was not unfamiliar with your language. I came from a family that valued learning. I also have much Latin and more Greek.

WILLIAM: I don't.

HUGH: I know.

WILLIAM: Speak to me in your language. Sing to me.

HugH: That is not possible.

WILLIAM: Sing - speak to me in your own language.

HuGH: You are hearing your own language. When the English destroyed us and our tribe, we made a vow. We had lost power to govern our lives and part of that curse was the loss we accepted over the government of our tongue. We do not break 
our vows. I will not sing nor speak to you in Irish, Englishman.

(McGuinness 1997:68)

Real, albeit fraught, cultural exchange is taking place here and Shakespeare is learning from the Irish. McGuinness has produced a nice, neat piece of stage dialogue which shows reciprocal cultures in action, which represents the learned Irish recognising that the brave new world they both inhabit may be principally English and effectively monoglot. The sly joke about Shakespeare's "small Latin and less Greek" also refers the alert members of the audience to Brian Friel's Translations (1980), which represented the destruction of a Gaelic civilization at the hands of more powerful and thorough nineteenth-century imperialists eager to map the country, exposing its secrets to the colonial gaze. Mutabilitie is situated at a pivotal point in Irish history, one that looks as if dialogue is still possible between open-minded parties on either side of the divide. However, if we are familiar with contemporary Irish drama - or, even just the course of subsequent history - we will know that the traffic is moving in one direction and the irritating resistance of the native Irish to the forces of the English crown will not persist. Shakespeare's plays represent Ireland as a powerful cultural presence, one that threatens to undermine the stability of England. Nearly four centuries later Irish dramatists, while still sympathetic to the bard, recognised the part that his drama had played in the destruction of their native culture.

\section{References}

Bacon, Francis 1972. Essays. Ed. Michael Hawkins. London: Dent.

Baker, David J. 1997. "Where is Ireland in The Tempest?" Eds. Mark Thornton Burnett and Ramona Wray. Shakespeare and Ireland: History, Politics and Culture. Basingstoke: Macmillan.

Baldwin, T. W. 1965. On the Compositional Genetics of The Comedy of Errors. Urbana: University of Illinois Press.

Baldwin, William 1988. Beware the Cat: The First English Novel. Ed. William A. Ringler, Jr. and Michael Flachmann. Huntington Library: San Marino, California.

Bate, Jonathan. 2008. Soul of the Age: The Life, Mind and World of William Shakespeare. London: Viking. 
Bradshaw, Brendan, Andrew Hadfield and Willy Maley, eds. 1993. Representing Ireland: Literature and the Origins of Conflict, 1534-1660. Cambridge: Cambridge University Press.

Bullough, Geoffrey 1962. Narrative and Dramatic Sources Of Shakespeare. 8 Vols. London: Routledge.

Connolly, S. J. 2007. Contested Island: Ireland 1460-1630. Oxford: Oxford University Press.

Derricke, John 1883 (1581). The Image of Irelande. Ed. J. Small. Edinburgh: Adam and Charles Black.

Edwards, Philip 1979. Threshold of a Nation: A Study in English and Irish Drama. Cambridge: Cambridge University Press.

Ellis, Steven G. 1985. Tudor Ireland: Crown, Community and the Conflict of Cultures, 1470-1603. Harlow: Longman.

Fletcher, Alan J. 200o. Drama, Performance, and Polity in Pre-Cromwellian Ireland. Cork: Cork University Press.

Greenblatt, Stephen and Peter G. Platt, eds. 2014. Shakespeare's Montaigne: The Florio Translation of the Essays: A Selection. New York: New York Review of Books.

Gresham, Stephen 1981. "William Baldwin: Literary Voice of the Reign of Edward VI." The Huntington Library Quarterly 44: 101-16.

Grogan, Jane 2013. "Three Essays on Spenser and the Twentieth Century: Spenser's Lost Children." Spenser Studies XXVIII: 1-54.

Hadfield, Andrew 2004. Shakespeare and Renaissance Politics. London: Thomson Learning.

Hamilton, Donna B. 1990. Virgil and The Tempest: The Politics of Imitation. Columbus: Ohio State University Press.

Herron, Thomas. 2013. "War, The Boar and Spenserian Politics in Shakespeare's Venus and Adonis." Eds. Willy Maley and Rory Loughnane. Celtic Shakespeare: The Bard and the Borderers. Farnham: Ashgate.

2006. "Plucking the Perrot: Muiopotmos and Irish Politics." Ed. J. B. Lethbridge. Edmund Spenser: New and Renewed Directions. Madison: Fairleigh Dickinson University Press.

Ivic, Christopher 2013. "Shakespeare's England/Jacobean Britain." Eds. Willy Maley and Rory Loughnane. Celtic Shakespeare: The Bard and the Borderers. Farnham: Ashgate.

Knowles, James, ed. 2001. The Roaring Girl and Other City Comedies. Oxford: Oxford University Press. 
Lennon, Colm 1995. Sixteenth-Century Ireland: The Incomplete Conquest. Dublin: Gill and Macmillan.

Levack, Brian P. 1987. The Formation of the British State: England, Scotland and the Union of 1603. Oxford: Clarendon Press.

McGuinness, Frank 1997. Mutabilitie. London: Faber.

McMillin, Scott 1999. "Professional Playwrighting." Ed. David Scott Kastan. A Companion to Shakespeare. Oxford: Blackwell.

Maley, Willy 1997a. Salvaging Spenser: Colonialism, Culture and Identity. Basingstoke: Macmillan.

1997b. "Shakespeare, Holinshed and Ireland: resources and ConTexts." Eds. Mark Thornton Burnett and Ramona Wray. Shakespeare and Ireland: History, Politics, Culture. Basingstoke: Macmillan.

Maslen, Robert 1997. Elizabethan Fictions: Espionage, Counter-Espionage and the Duplicity of Fiction in Early Elizabethan Prose. Oxford: Oxford University Press.

Middleton, Thomas 2007. The Collected Works. Eds. Gary Taylor and John Lavagnino. Oxford: Oxford University Press.

Morash, Christopher 2000. A History of the Irish Theatre, 1601-2000. Cambridge: Cambridge University Press.

Morgan, Hiram 1995. "The Fall of Sir John Perrot." Ed. John Guy. The Reign of Elizabeth I: Court and Culture in the Last Decade. Cambridge: Cambridge University Press. 109-25.

Mottram, Stewart 2013. "Warriors and Ruins: Cymbeline, Heroism and the Union of Crowns." Eds. Willy Maley and Rory Loughnane. Celtic Shakespeare: The Bard and the Borderers. Farnham: Ashgate.

Neill, Michael 1994. "Broken English and Broken Irish: Nation, Language, and the Optic of Power in Shakespeare's Histories." Shakespeare Quarterly 45: 1-32.

Ó Ciardha, Éamonn, and Micheál Ó Siochrú, eds. 2012. The Plantation of Ulster: Ideology and Practice. Manchester: Manchester University Press.

Patterson, Annabel 1989. Shakespeare and the Popular Voice. Oxford: Blackwell.

Pettegree, Andrew 2014. The Invention of Nezus: How the World Came to Know about Itself. New Haven: Yale University Press.

Plunket Barton, D. 1919. Links between Shakespeare and Ireland. Dublin: Maunsel.

Power, Andrew 2013. "'Why Should I Play the Roman Fool, and Die / On Mine Own Sword?': The Senecan Tradition in Macbeth." Eds. Willy Maley and Rory Loughnane. Celtic Shakespeare: The Bard and the Borderers. Farnham: Ashgate. 
Rankin, Deana 2005. Between Spenser and Swift: English Writing in SeventeenthCentury Ireland. Cambridge: Cambridge University Press.

Ringler, William A., Jr. 1978-9. "Beware the Cat and the Beginnings of English Fiction'. Novel 12: 113-26.

Rowley, William, Thomas Dekker and John Ford. 1997. The Witch of Edmonton. Manchester: Manchester University Press.

Shakespeare, William 1975. As You Like It. Ed. Agnes Latham. London: Methuen.

- 1980. The Tempest. Ed. Frank Kermode. London: Methuen.

- 1982. Henry V. Ed. Gary Taylor. Oxford: Oxford University Press.

1990. Macbeth. Ed. Nicholas Brooke. Oxford: Oxford University Press.

- 1999. King Henry VI, Part II. Ed. Ronald Knowles. London: Nelson.

2002. King Richard II. London: Thomson.

2004. The Comedy of Errors. Ed. T. S. Dorsch. Cambridge: Cambridge University Press.

Shapiro, James 2005. 1599: A year in the Life of William Shakespeare. London: Faber.

Sheehan, Bernard W. 1980. Savagism and Civility Indians and Englishmen in Colonial Virginia. Cambridge: Cambridge University Press.

Shirley, James 1640. St. Patrick for Ireland: The first part. London. 1655. The Polititian, a tragedy. London.

Silke, John J. 1970. Kinsale: The Spanish intervention in Ireland at the End of the Elizabethan Wars. Liverpool: Liverpool University Press.

Sonner, Helen Jeanine 2013. "Print, Rhetoric, and 'Plantation', 1571-1641." Ph. D. thesis. Queen's University, Belfast.

Tillyard, E. M. W. 1969. Shakespeare's History Plays. Harmondsworth: Penguin.

How to cite this article:

Hadfield, Andrew. "Grimalkin and other Shakespearean Celts." SEDERI 25 (2015): 55-76.

Author's contact: a.hadfield@sussex.ac.uk

Postal address: School of English, University of Sussex - Falmer, Brighton - Sussex BN1 9QN, UK 